\title{
RESULTADOS DAS SONDAXES NUN XACEMENTO ATÍPICO DA IDADE DO FERRO: PENA REDONDA (PONTECALDELAS, PONTEVEDRA)
}

\author{
ALFREDO GONZÁLEZ RUIBAL
}

\begin{abstract}
Resumen
O xacemento de Pena Redonda é coñecido desde 1981 a raíz dunha intervención furtiva que sacou á luz restos dunha estructura circular e material da Fase I e II da Cultura Castrexa (800400 a. C. / 400-100 a.C.). O interese do sitio radica no seu estraño emprazamento, perto dunha chan elevada e dominado por un outeiro. A paisaxe, onde abundan os petroglifos, é máis propia do Bronce que do Ferro, e o lugar tampouco posúe unha morfoloxía típica de castro. A escavación de dúas cabanas, que foran afectadas polos furtivos, deu como resultado a constatación dunha longa ocupación durante as fases I e II, o que fai desbotar a idea de que se trate dun lugar de habitación ocasional e traza cuestións sobre a elección deste lugar determinado. A densidade histórica dos arredores e o particular escenario natural son indubidablemente factores que hai que ter en conta. A inexistencia de niveis posteriores ao século II a. C. -que permitiu a boa conservación dos restos prerromanos- reforza, se cabe, o interese deste xacemento.
\end{abstract}

\section{Palabras Clave}

Edad del Hierro. Noroeste de la Península Ibérica. Cultura Castreña. Asentamiento abierto. Secuencia de ocupación.

\begin{abstract}
The settlement site of Pena Redonda was firstly known in 1981 after an unauthorized excavation that revealed the remains of a round hut and associated materials, belonging to the phases I and II of the Castros Culture (800-400 BC / 400-100 $\mathrm{BC}$ ). The main singularity of the site comes from the atypical location, in the flat highlands and at the bottom of a small hill. This placement, together with the abundance of rock carvings, constitute a typical Bronze Age landscape rather than an Iron Age one; besides, the site itself lacks the characteristic shape of a hillfort. The archaeological excavation of two huts, previously affected by the illicit works, documented the existence of a long term occupation of the site throughout the phases I and II, which discards the possibility of a seasonal or short term use of the site and poses the question of the selection of this specific location. The historical density of the surroundings and the particular conditions of the natural environment are both factors to be considered. The absence of archaeological contexts following the II century $\mathrm{BC}$ (which allowed a good preservation of the preroman remains) remarks the interest of this site.
\end{abstract}

\section{Key Words}

Iron Age. Northwest of the Iberian Peninsula. Castros Culture. Open settlement. Sequence of occupation. 


\section{INTRODUCCIÓN}

Durante o mes de marzo de 2003 levouse a cabo unha intervención arqueolóxica de carácter limitado no xacemento arqueolóxico de Pena Redonda (GAX36043015). O sitio atópase no monte comunal de Forzáns (concello de Pontecaldelas, provincia de Pontevedra), nas estribacións da Dorsal Meridiana (Figura 1). Procedentes de dito lugar, aínda que aparecesen co topónimo erróneo de «Chan das Pipas», tiven ocasión de analizar uns materiais cerámicos que claramente pertencían a Idade do Ferro, tanto a Fase I como a II/III da Cultura Castrexa (s. VIII-V a.C. e s. IV-I a.C.) ${ }^{1}$. Foi precisamente o debandito topónimo, o facto de que o lugar non se chamase «castro», senón «chan»-que en principio parece máis apropiado para un xacemento do Bronce-, o que me levou a visitar o lugar. O emprazamento, como se verá a continuación, sen ser unha chan, si se desvía do que é norma na Idade do Ferro. Sobre o terreo podíase apreciar a existencia de numerosos derrubes procedentes de estruturas e restos de dúas cabanas circulares parcialmente escavadas. A primeira intervención non tivo un carácter anticuario: todos os arredores do monte están furados polos veciños das aldeas do val que extraen de aquí a auga necesaria para regar os seus campos, situados debaixo do monte no que se atopa o xacemento. Na escavación dunha destas minas de auga saíu á luz a cabana que denominamos casa 1 . Sabendo da existencia de restos antigos exhumadas nestas tarefas, Dna. María Albertina Boullosa, veciña da Pousa (Caritel) levou a cabo a súa propia intervención, que

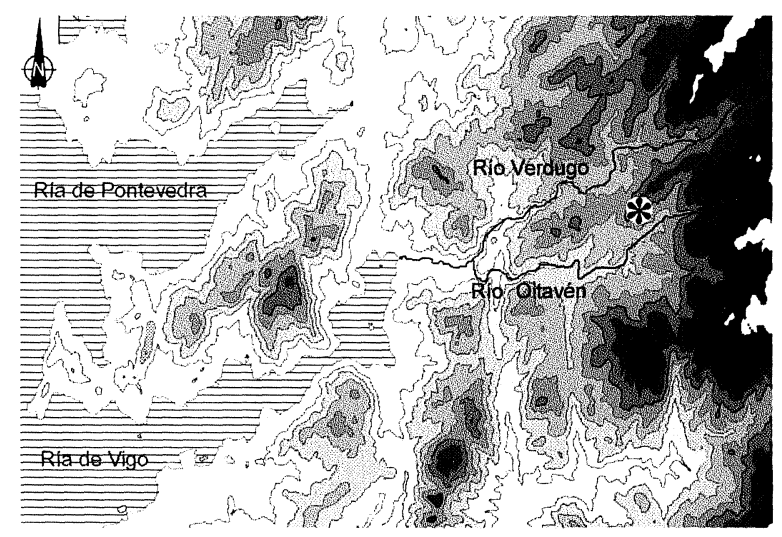

Figura 1. Ubicación de Pena Redonda.

' Falaremos aquí de Primeira Idade do Ferro (s. VIII-V a.C.) e Segunda Idade do Ferro (s. IVI a.C.) que se corresponden, respectivamente, coa Fase I e II/III da Cultura Castrexa. 
tivo como resultado a descoberta da que denominamos casa 2. Non recollemos tradicións lendarias referentes aos restos do lugar que, significativamente, carecen de topónimo de seu. Preguntados os veciños sobre o nome do lugar dubidan entre Pena Redonda e Chan da Sobreira. O lugar nunca foi denominado castro. As lendas que se nos contaron corresponden aos petroglifos do redor e máis á cercana Pena Redonda, sen que se faga mención a mouros, casas castrexas ou demáis elementos presentes no corpus de lendas dos xacementos do Ferro.

Visto o interese do sitio, decidiuse solicitar un permiso de sondaxe de modo que se poidesen contextualizar os materiais depositados no museo e as estruturas descobertas ${ }^{2}$.

\section{EMPRAZAMENTO E TOPOGRAFÍA: UNHA PAISAXE ATÍPICA}

O que máis chama a atención do xacemento de Pena Redonda é o seu peculiar emprazamento. Ubícase nunha pequena elevación ao final dunha chan, coñecida polos nomes de Campo Grande (N) e Campo Pequeno (S), nas cais hai unha mámoa e varias concentracións de petroglifos (Figura 2). Esta chan, que se extende ao oeste do xacemento, está parcialmente inundada incluso en verán e áchase arrodeada de pequenos cotos cónicos de superficie rochosa. A ladeira que sube desde o sur ao xacemento coñécese como Chan da Sobreira, topónimo que chega até o pé mesmo do sitio. O xacemento sitúase a 526 metros de altura, entre o afloramento de Pena

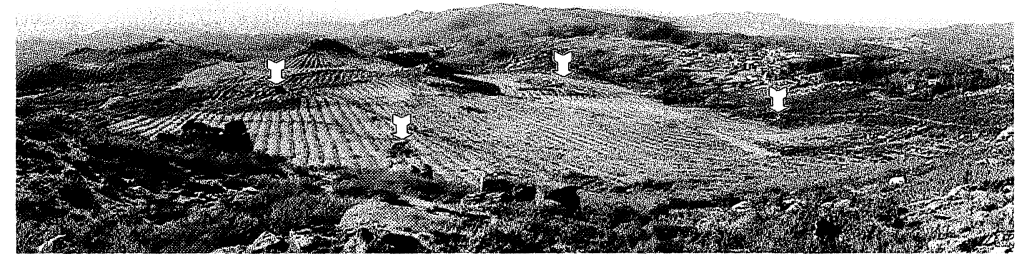

Figura 2. Campo Grande e Campo Pequeno. As frechas asinalan a presenciad e petroglifos.

${ }^{2} \mathrm{~A}$ intervención arqueolóxica enmárcase dentro do proxecto da miña tese de doutoramento sobre o primeiro milenio a.C. no Noroeste da Península Ibérica, que dirixe o prof. Dr. Gonzalo Ruiz Zapatero, da Universidade Complutense de Madrid. A tese de doutoramento é financiada polo Ministerio de Educación e Cultura cunha bolsa de Formación de Profesorado Universitario. 
Redonda $(540 \mathrm{~m})$, composto por varios característicos penededos, e as chans menzoadas (Figura 3). O asentamento ten uns eixos máximos NE-SW e NW-SE de 65 metros. A superficie total do sitio non debía chegar os $4.000 \mathrm{~m}^{2}$. Tanto as chans, como os afloramentos e o sitio no que se empraza o asentamento prehistórico aparecen dominados por un outeiro de grandes dimensións que corre en sentido surlestenoroeste (Figura 4) e que recibe o nome de Coto da Cavada $(586 \mathrm{~m}$ ). A visibilidade desde o xacemento é excepcional: chega até os 45 quilómetros en liña recta, que é a distancia á que se sitúan as illas Cíes, perfectamente visibles os días despexados e húmidos. Tamén entran dentro do seu control visual, entre outros, o castro da Peneda do Viso (16 qm lineais) e o Castro Barbudo (3,5 qm), cara o sudoeste; o castro de Tourón (8 qm), cara o oeste; e o castro de Gaxate (1 qm), cara o leste. O río Oitavén vese en varios tramos e, se ben non é controlable o río Verdugo, si o son as estribacións do seu val. A Serra do Suido, polo oeste, pon límite a visibilidade do lugar.

Dada a súa altitude relativa, a presencia de petroglifos nas inmediacións (Figura 5), os afloramentos rochosos e a ausencia de campos de cultivo de solos profundos estaríamos ante un lugar característico da Fase I da Cultura Castrexa. Non obstante, existen elementos discordantes: non só escasean os solos de cultivo profundos senón tamén os lixeiros: o único uso rendable é o gandeiro, que é, ademáis, o tradicional destas terras. Os solos cultivables máis cercanos áchanse a 1,5 km lineais, mais cómpre ter en conta que se sitúan todos nunha dirección (S), que non son visibles desde o xacemento e que hai un grande desnivel (uns douscentos metros). Por outra banda, ben que a visibilidade elevada é característica dos máis antigos castros, tamén é certo que no outeiro que domina o sitio as vistas son aínda mellores e posúe menos áreas ocultas polos pequenos cotos que pechan as chans arriba menzoadas. Desde o punto de vista da visibilización, o lugar resulta bastante deficiente. Só é claramente recoñecible unha vez que se está arriba, nas chans. Desde abaixo, calquera dos pequenos cotos constitúe unha boa referencia paisaxística, mentras que a Pena Redonda é invisible. Ademáis, a morfoloxía característica dos primeiros castros ou lugares elevados é a dun monte cónico, defendido naturalmente. O lugar, neste caso, non é cónico, nen se afasta do relevo circundante como, pongamos por caso, a Peneda do Viso ou o Facho de Donón, por menzoar dous exemplos cercanos. A defensa natural dase polo leste esclusivamente, pero, mesmo así, sen elementos artificiais o asentamento é fácilmente accesible. Polo oeste a subida é moi lene desde as chans -o que motivou, quizáis, a construcción dunha posible muralla-. Polo norte, como xa dixemos, o xacemento está dominado por un coto máis alto: a única forma de defensa sería arrodear todo este outeiro con murallas, pois aínda se se construíse unha muralla que separase a Pena Redonda do coto, aquela ficaría baixo as armas dos posibles asaltantes. O mellor 


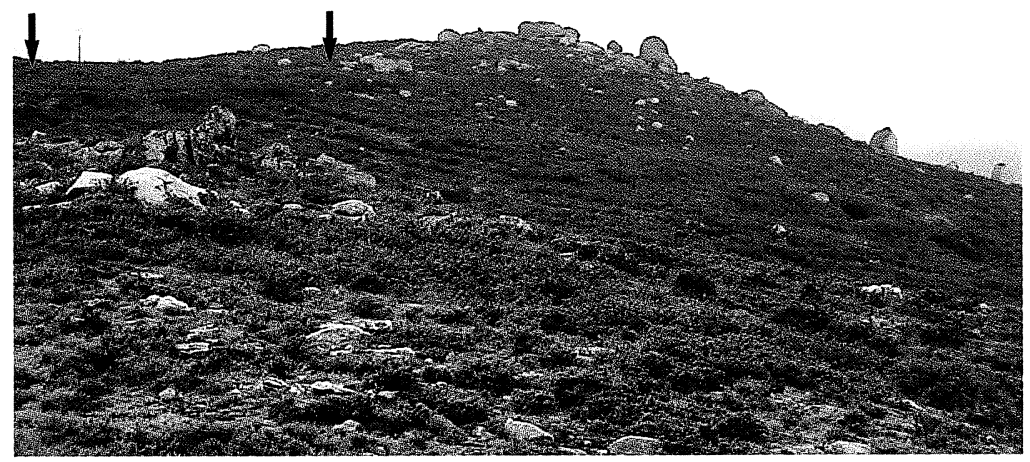

Figura 3. Ubicación do xacemento -entre as frechas-, ao norte da Pena Redonda.

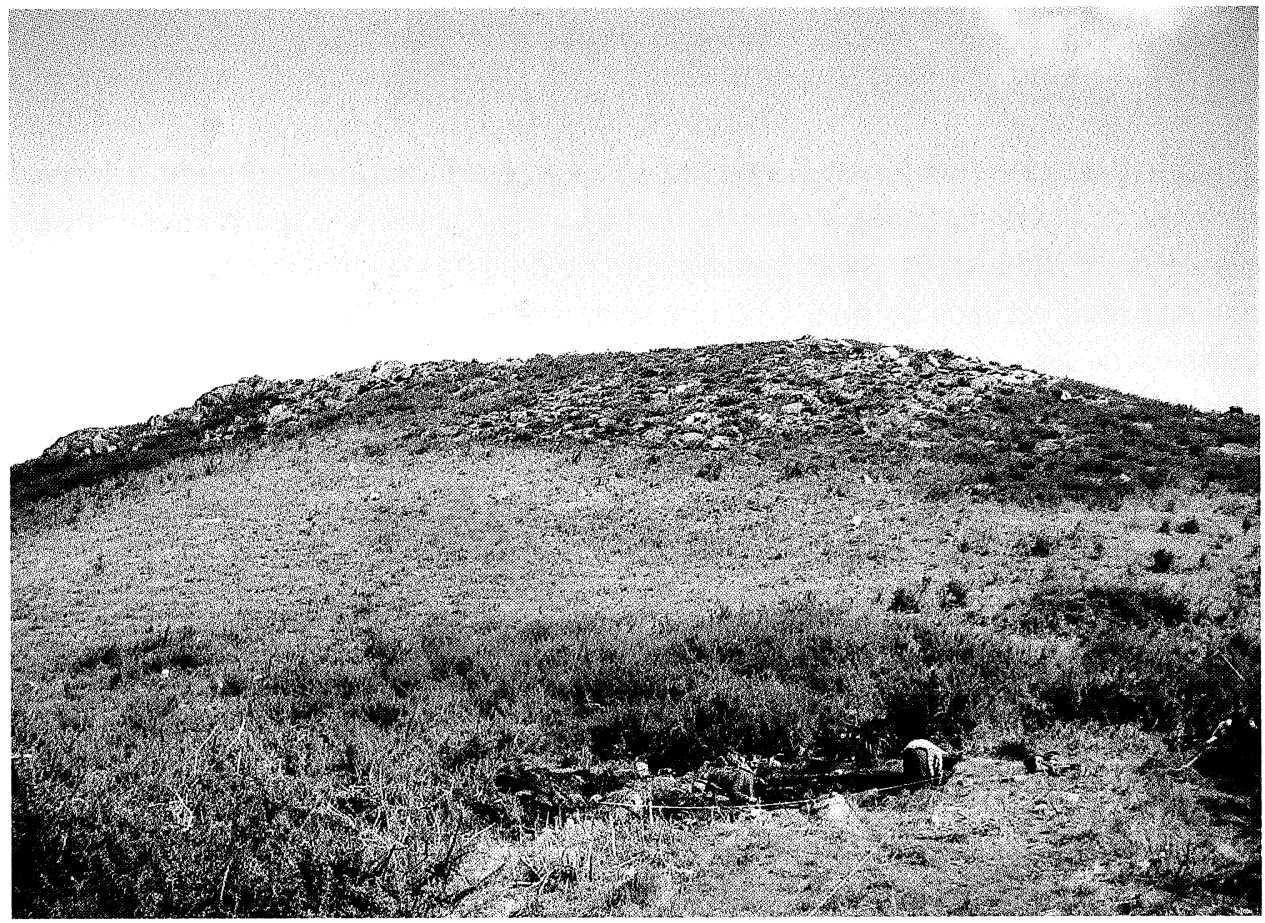

Figura 4. Outeiro que domina o xacemento.

Cuadernos de Estudios Gallegos, Tomo LII, Fascículo 118, Santiago 2005. (Págs. 173 - 197) 


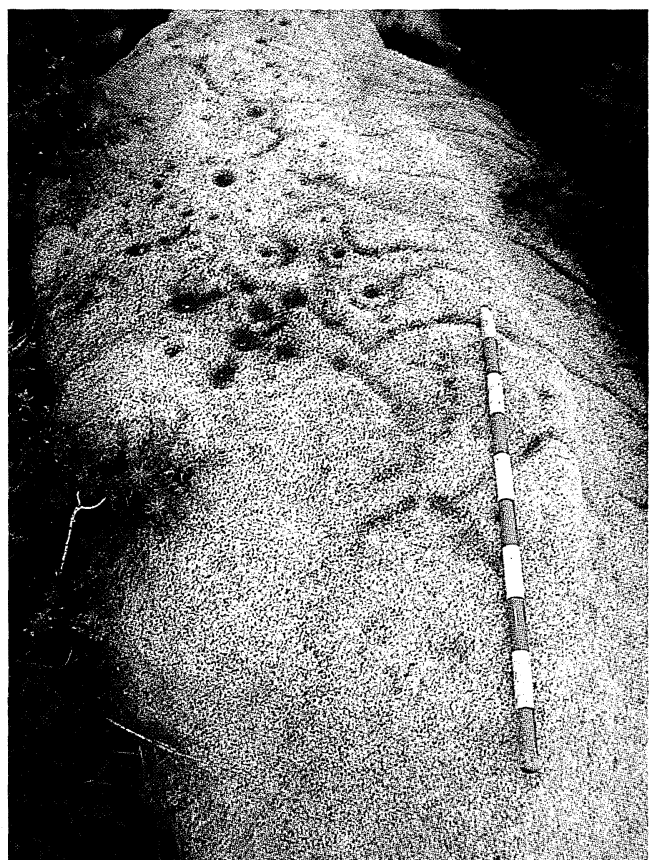

Figura 5. Petroglifo do Campo Pequeno.

paralelo para este sitio é o de Barbudo na Fase I, entre finais do segundo milenio e os finais da Primeira Idade do Ferro (Martins 1989). Durante o seu primeiro medio século de existencia, este asentamento carece de defensas e ademáis non se sitúa na parte máis elevada do monte no que se empraza, senón nunha ladeira. As limitadas sondaxes e a ocupación posterior non permitiron aprofundar na organización do espacio e a funcionalidade dese lugar, pero, polo menos para a fase do Bronce Final (s. XII-IX a.C.) parece que se trataba dun povoado dependente do castro de São Julião (Bettencourt 2000a), mentres que aquí non existe relación xerárquica posible con outro asentamento.

Se durante a Fase I podemos admitir a existencia de emprazamentos atípicos e morfoloxías pouco definidas, isto parece menos doado para a Fase II (s. IV-II a.C.). Sen embargo, durante a Segunda Idade do Ferro sabemos que este xacemento segue en activo, como veremos. Non posúe a característica forma redonda ou ovalada da práctica totalidade dos castros do Noroeste ibérico, nen conta cun perímetro fortificado: todo o máis cubriría o lado máis exposto cunha liña defensiva (o que lembra aos castros costeiros). A parte a carón da Pena Redonda continúa sen ser utilizada, polo menos non como área de habitación, dado que o afloramento surxe por todas partes. 
A presencia de mámoas e numerosos petroglifos nas inmediacións do xacemento -os máis cercanos están a escasos cen metros lineais-, a existencia de chans de altura, o territorio gandeiro de monte baixo, todo leva a pensar nunha paisaxe da Idade do Bronce máis que da Idade do Ferro, tal e como a define Criado (1993: 38). Falando dos asentamentos desta época escrebe: «En general se sitúan siempre en zonas de monte, en el piso topográfico inmediatamente superior al ocupado por las aldeas y terrenos de cultivo intensivo actuales. Puntualmente se vinculan a brañas de cierto desarrollo y que podrían haber sido utilizadas como zonas de reserva de humedad para pasto de verano». Se a isto lle engadimos os numerosos petroglifos que arrodean as chans (Figura 2), a coincidencia coa descrición é perfecta. $\mathrm{O}$ facto de que o sitio non sexa visible, ademáis, pode corresponderse con un modo de deambulación propio do Neolítico ou da Idade do Bronce. Para quenes se moven polas chairas elevadas, entre portelas e camiños de monte, a Pena Redonda si constitue un fito importante na paisaxé.

Se ben é verdade que os inicios do Ferro amosan certa continuidade co Bronce (Parcero 2001), o certo é que neste caso nen o asentamento propiamente dito nin o espacio circundante amosan elementos claros de ruptura co escenario anterior. A xeralización dunha determinada paisaxe fortificada en Galicia a partir do século VIII a.C., douscentos anos antes no norte de Portugal, non debeu impedir a pervivencia de sitios marxinais que continuaban unha tradición moi antiga. Agora ben, esta pervencia haberá que explica-la en termos funcionais, simbólicos ou ambos. Desde o punto de vista funcional poderíase entender que o asentamento está adicado a explotación de recursos gandeiros, pero isto non sería óbice para a súa ubicación nunha paisaxe máis «castrexa»-xa se sinalaron as posibilidades-. O escenario histórico e natural no que se insire o xacemento fai pensar que o significado cultural e a reelaboración dos signos da paisaxe, neste caso como en outros, debeu ter un lugar preeminente na elección e perduración do asentamento.

A todas as cuestións menzoadas cómpre engadir un outro elemento de interese: o torques do Río Oitavén, pertencente a Primeira Idade do Ferro (s. VIII-V a.C.). Este torques de ouro foi atopado na marxe do debandito río nos anos 10 do século XX no lugar de Ponte Vilán (López Cuevillas 1951: 34-35) e trátase do único exemplar desta época atopado na provincia de Pontevedra. En toda Galicia só se ten achado un máis, na provincia de Lugo (Santa María de Rendar, O Incio) (Balseiro 1994: 58-59). O asentamento da Fase I máis cercano ao lugar de achádego desta xoia é, precisamente, o de Pena Redonda, que está a uns 2,5 km ao norte do sitio en cuestión e o controla visualmente. As ofrendas ás augas constitúen unha perduración dos ritos do Bronce Final durante os inicios do Ferro - outro caso sería o puñal do río Mero (O Burgo, A Coruña) (Meijide 1988: lám. 26)- e a súa simboloxía 
como sinalización de fronteiras humanas e míticas pode continuar mesmo durante a época castrexa. Precisamente o río Oitavén supón unha fronteira entre o espacio habitado (ao norte) e o baleiro poboacional de Fornelos de Montes, onde non hai vestixios da Idade do Ferro (cf. Carballo 1996: 123 e Figura 4), debido a súa esgrevia xeografía. Tamén Pena Redonda, nas abas da Serra do Suido, áchase nun límite entre o humano e o natural. Asi pois, o carácter liminal e o seu vencello a outros lugares liminais marcados ritualmente son aspectos para ter en conta ao tentarmos de comprender o xacemento.

\section{LOCALIZACIÓN DA ÁREA INTERVENCIONADA E ACTUACIÓNS PREVIAS}

A intervención realizada durante nove días útiles en marzo de 2003 centrouse en dúas estruturas circulares de pedra sacadas á luz por furtivos. Sitúanse a unha vintena de metros cara o noroeste da Pena Redonda. Orixinalmente tiñase previsto facer unha sondaxe na posible muralla e outra nunha estrutura lineal que pechaba o lugar cara o norte. Polas limitación de tempo e persoal, decidiuse deixar estas sondaxes para unha segunda campaña. Por outro lado, o presunto muro de peche cara o norte resultou non ser tal. Esta zona achábase relativamente limpa de toxo pola presencia de gando, o que forneceu un panorama diferente ao percibido en ocasións anteriores (marzo e agosto de 2002). A estrutura non tiña un carácter lineal, senón que formaba parte dun muro de maiores dimensións e de forma rectangular. Máis ao oeste existe outra estrutura similar. A cronoloxía e funcionalidade fican pendentes dunha segunda intervención.

- A casa 1, a máis meridional, foi escavada antes de 1981 probablemente por veciños de Forzáns ou dos arredores. O único achádego vencellable a esta estrutura é un fragmento de torques ou colar en bronce depositado no Museo de Pontevedra e que localizou Dna. $\mathrm{M}^{\mathrm{a}}$ Albertina Boullusa tempo despois de que a cabana fose expoliada, no sector NE daquela. A intervención afectou só a parte interior da cabana e chegou por todas partes até a rocha nai. Detrás da casa 1, cara o leste e sur, exténdese xa o afloramento rochoso o que fai pouco probable que continuase por aí o povoado.

- A casa 2 áchase a uns 20 metros ao nornoreste da outra estrutura. Como resultado da intervención da Sra. Boullosa ficou exhumada a metade dunha estrutura de paredes curvas, restos doutro muro que cortaba a estrutura curva e abundante material cerámico. Polas súas indicacións, podemos saber

Cuadernos de Estudios Gallegos, Tomo LII, Fascículo 118, Santiago 2005. (Págs. 173 - 197) 
que a maior parte do material apareceu dentro da cabana, mentres que no exterior atopouse unha vasilla de borde esvasado e decoración incisa metopada que se garda no Museo de Pontevedra, xunto co resto do material exhumado ${ }^{3}$. Tamén saíu unha doa de bronce que se desfixo ao pouco de extraela. Neste caso, a intervención afectou tamén a parte exterior da cabana: a Sra. Boullosa escavou parte do exterior norte da estrutura seguindo o muro. Pola contra, non se chegou a perturbar máis que o nivel da Segunda Idade do Ferro no interior e parte do último nivel da Primeira Idade do Ferro. Desgraciadamente, a técnica utilizada neste caso para abrir a cabana foi cavar unha fosa en dirección oeste-este que destruiu o muro da estrutura curva e perturbou gravemente os niveis situados máis cara o oeste da cata. Precisamente ao oeste, fora da cabana, sitúase a pedreira principal, producto da intervención non controlada. En ningures esgotáronse os niveis arqueolóxicos.

\section{METODOLOXÍA}

Prantexáronse dúas sondaxes de 7x7 metros (casa 1) e de $7 \times 4$ metros (casa 2) respectivamente, que pretendían ocupar toda a área orixinal das cabanas máis o seu exterior. En ámbolos dous casos tratábase de comprobar o contexto estratigráfico interior e exterior das estruturas, que permitise contextualizar os materiais exhumados clandestinamente, e o alcance da actividade furtiva.

- Na casa 1 limpiouse o sedimento depositado tra-la acción furtiva e perfiláronse os lados norte e oeste que ficaron entón sen escavar. Unha vez feito isto, procedeuse a escavar o paquete intacto dentro da cabana, máis oito metros ao norte, tres o sur e oito ao leste, de forma que se poidese recuperar a pranta da cabana, a súa relación con outras posibles estruturas e co exterior e documentar os niveis interiores da estrutura non tocados polos furtivos. A escavación realizouse en extensión sen deixar testigos e rexistrouse a información por unidades estratigráficas.

- Na casa 2 tras realizarse a limpeza decidiuse abrir catro metros cara o norte, catro cara o leste e todo o interior sen alterar da estrutura curva. A escavación realizouse como no caso anterior.

\footnotetext{
${ }^{3}$ Os debuxos de todo o material foron adxuntados coa memoria de solicitude deste proxecto remitido ao Servicio de Arqueoloxía da Xunta de Galicia.
}

Cuadernos de Estudios Gallegos, Tomo LII, Fascículo 118, Santiago 2005. (Págs. 173 - 197) 
O material recolleuse por unidades estratigráficas e, cando éstas eran amplas, por cadros de 1x1 metros. Coordenáronse os materiais máis destacables. A planimetría fíxose a escala $1 / 10$. Debuxáronse os dous perfís estratigráficos menzoados na casa 1 e o perfil leste e o sur na casa 2, ademáis do que se puido recuperar baixo o muro da cabana espoliada.

\section{RESULTADOS DA INTERVENCIÓN NA CASA 1}

Da casa 1 escavouse a extensión suficiente como para poder definir todo o seu perímetro (Figura 6). O resultado foi unha cabana de 5,20 metros (E-W) por 4,50 metros $(\mathrm{N}-\mathrm{S})$ e pranta ovalada. Trátanse dunhas dimensións típicas para as cabanas da Segunda Idade do Ferro.

\section{Interior}

Unha vez que se perfilaron os cortes deixados polo furtivo, poidemos ler unha serie estratigráfica (Figura 7) que incluía polos menos dous niveis fértiles, o máis recente do cal pertencía a cabana de pedra. Debaixo do derrube da estrutura (UE 15) apareceu un nivel da Segunda Idade do Ferro composto por dúas unidades estratigráficas (UE 9: pavemento e UE 8: nivel de ocupación) O pavemento, de xabre compactado e cor ocre, achábase en moi mal estado de conservación. Os materiais foron moi escasos: tan só dous bordes, dos cais un deles presentaba a arista interior típica do segundo Ferro (Figura 8A). Na UE 8 recolleuse un anaco de carbón para datar. Levantado o pavemento aparece unha camada de cor escura, moi orgánica (UE 10), que, polo lado oeste, está cubrindo unha cubeta de xabre, parcialmente delimitada por pedras (UE 16). Este nivel pertence a Primeira Idade do Ferro: recuperáronse algúns materiais típicos como bordes rectos tipo Neixón, unha parede con dixitacións e un mamilo (Figura 8B). A cubeta de xabre, que está disposta directamente sobre a rocha nai, semella, en principio, unha estrutura de fogar, pero non se descubriron restos de combustión de ningún tipo.

\section{Exterior}

Cara o leste abríronse oito metros cadrados que ofreceron pouca información. Baixo a capa vexetal e o derrube -onde o había- saiu un estrato único (UE 14) até a rocha nai que aflora moi pronto, especialmente no lado máis oriental e meridional da cata. $O$ facto de que a rocha nai apareza aquí tan pronto e que sexa máis superficial cara o leste indica que a casa 1 sitúase no límite do asentamento por esta banda. Nesta UE apareceu material bastante esnaquizado: bordes marítimos -

Cuadernos de Estudios Gallegos, Tomo LII, Fascículo 118, Santiago 2005. (Págs. 173 - 197) 


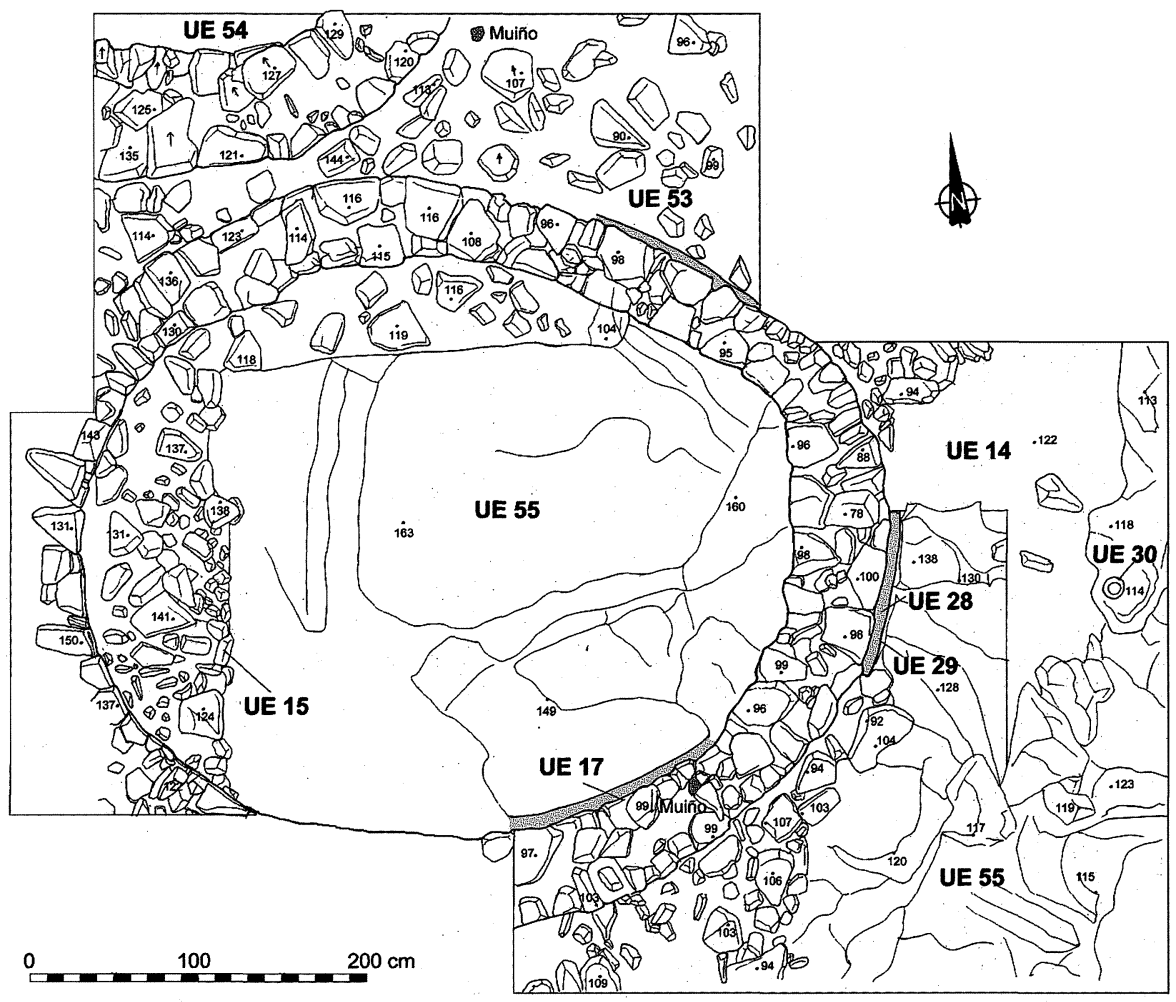

Figura 6 Casa 1.
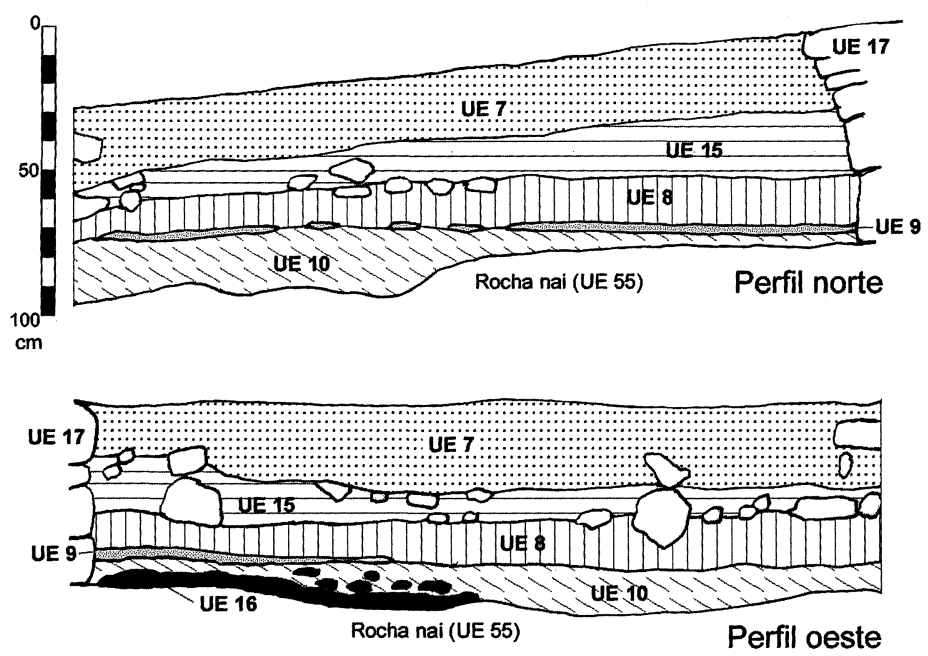

Figura 7. Estratigrafía interior da cabana. 


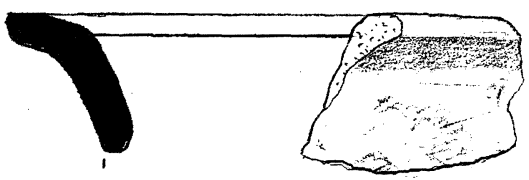

$\mathrm{PR} / 8 / 1$

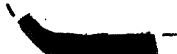

A

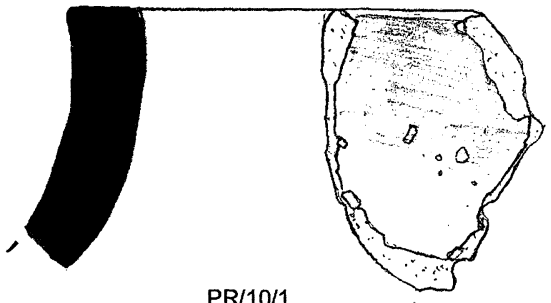

$\mathrm{PR} / 10 / 1$

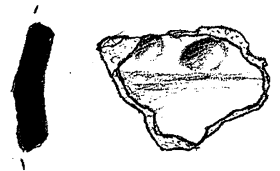

$\mathrm{PR} / 10 / 3$

B

\section{0}

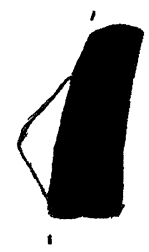

$\mathrm{PR} / 10 / 2$
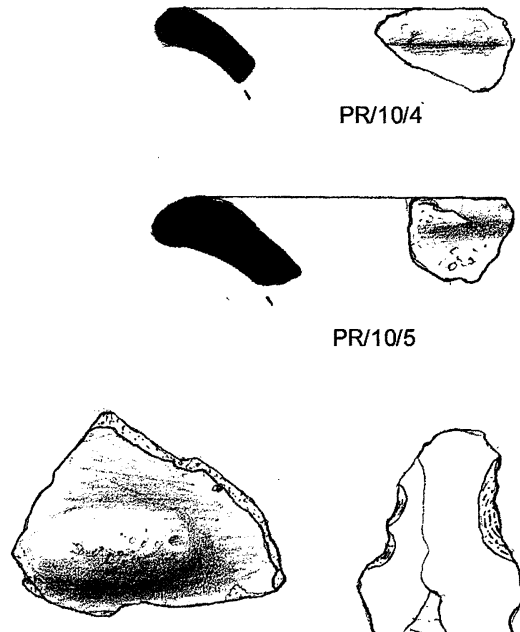

$\mathrm{PR} / 10 / 4$

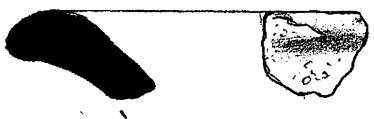

$\mathrm{PR} / 10 / 5$

Figura 8A. Materiais da UE 8 (Segunda Idade do Ferro). Figura 8B. Materiais da UE 10 (Segunda Idade do Ferro).

semellantes aos da Ría de Vigo- e aristados da Segunda Idade do Ferro e, no contacto coa rocha nai, algúns bordes esvasados e rectos de tradición do primeiro Ferro. A orientación e buzamento dos fragmentos indica que o estrato está revolto. Non se aprecia diferencia de coloración na UE. Localizouse tamén un núcleo de sílex melado -que demostra a existencia dun intercambio a longa distancia- e 
unha landra carbonizada, esta última por entre as pedras do derrube exterior (UE 3). Dado que o derrube exterior da cabana (UE 17) é moi limitado e concéntrase no sector máis septentrional e meridional da cata, pódese colixir que a cabana afundiu cara o interior, o que se explica polo pandeo dos muros. Na rocha nai apareceu un burato de poste (UE 30). Nos cadros abertos cara o norte da cabana localizouse unha nova estrutura de pranta circular (UE 54) que tamén venceu cara o interior, segundo se advirte no buzamento das pedras. Entre as dúas cabanas apareceu bastante derrube (UE 53) e moi escaso material cerámico da Segunda Idade do Ferro. Seguindo o perímetro da cabana polo exterior identificouse, tanto nos cadros do norte como nos do leste, a zanxa dos alicerces (UE 29) rechea de xabre (UE 28). A zanxa está escavada directamente na rocha nai ou na rocha meteorizada.

\section{RESULTADOS DA INTERVENCIÓN NA CASA 2}

A intervención clandestina e o exterior da cabana: a Segunda Idade do Ferro

A casa 2 é unha estrutura de paredes curvas (Figura 9) cuxo desenvolvemento polo de agora descoñecemos. Si podemos saber, pola leitura dos paramentos, que a metade occidental da cabana foi construida nun momento e a oriental noutro. A parte occidental (UE 12) amosa pedras de maior tamaño e pequenos chantos fincados nos alicerces, cousa que non atopamos na parte oriental (UE 52). O muro, especialmente a UE 12, está collido cunha masa a base de xabre, do cal se recolleron mostras para analizar. Podemos atribuir a esta estrutura todos os materiais cerámicos depositados no Museo de Pontevedra. Os materiais pertenecen, fundamentalmente, ao último nivel ou niveis de vida da cabana (Figura 10). En total a escavación non controlada forneceu 556 galbos, 41 bordes e 12 fondos, a meirande parte dos cais son da Segunda Idade do Ferro. Dentro dos bordes a porcentaxe de aristados ou facetados e de $53 \%$ (Figura 10, $\mathrm{n}^{\circ} 7-16$ ) o que achega o sitio a castros do interior e norte de Galicia. Algúns tipos de bordes aristados, non obstante, aparecen tamén na parte costeira e meridional da Cultura Castrexa, como é o caso da Forca (Carballo 1987: 115). Con todo, o número é inferior ao das rexións interiores: no debandito castro, a porcentaxe de vasillas aristadas e do $19 \%$. Xunto ás cerámicas aristadas temos unha imitación dun borde reforzado tipo Vigo (Rey 1990-91: 153) e algúns bordes engrosados marítimos (Figura 10, $\mathrm{n}^{\mathrm{0}} 2-3$ ), semellantes aos da Ría de Vigo. O primeiro xeralízase na Fase III mais está documentado desde a Fase II (Parcero e Cobas, n.p.). Os bordes engrosados abundan na Fase II. Tamén a tradición oleira meridional pertencen as vasillas de pequeno tamaño, bordes lixeiramente esvasados sen arista e superficies brunidas (Figura $10 n^{\circ} 4-6$ ). A decoración parece atoparse 


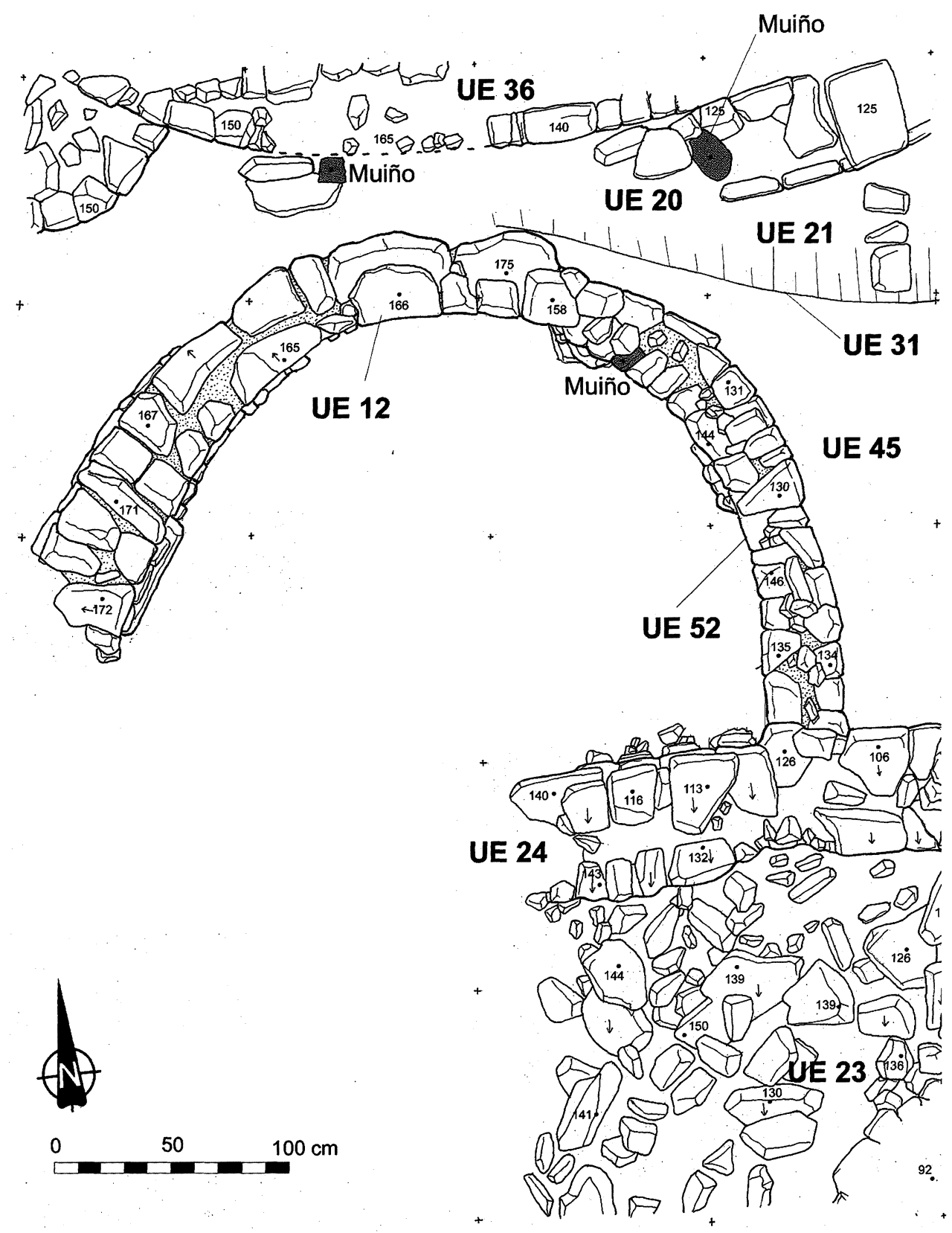

Figura 9. Casa 2. Estruturas da Segunda Idade do Ferro. 

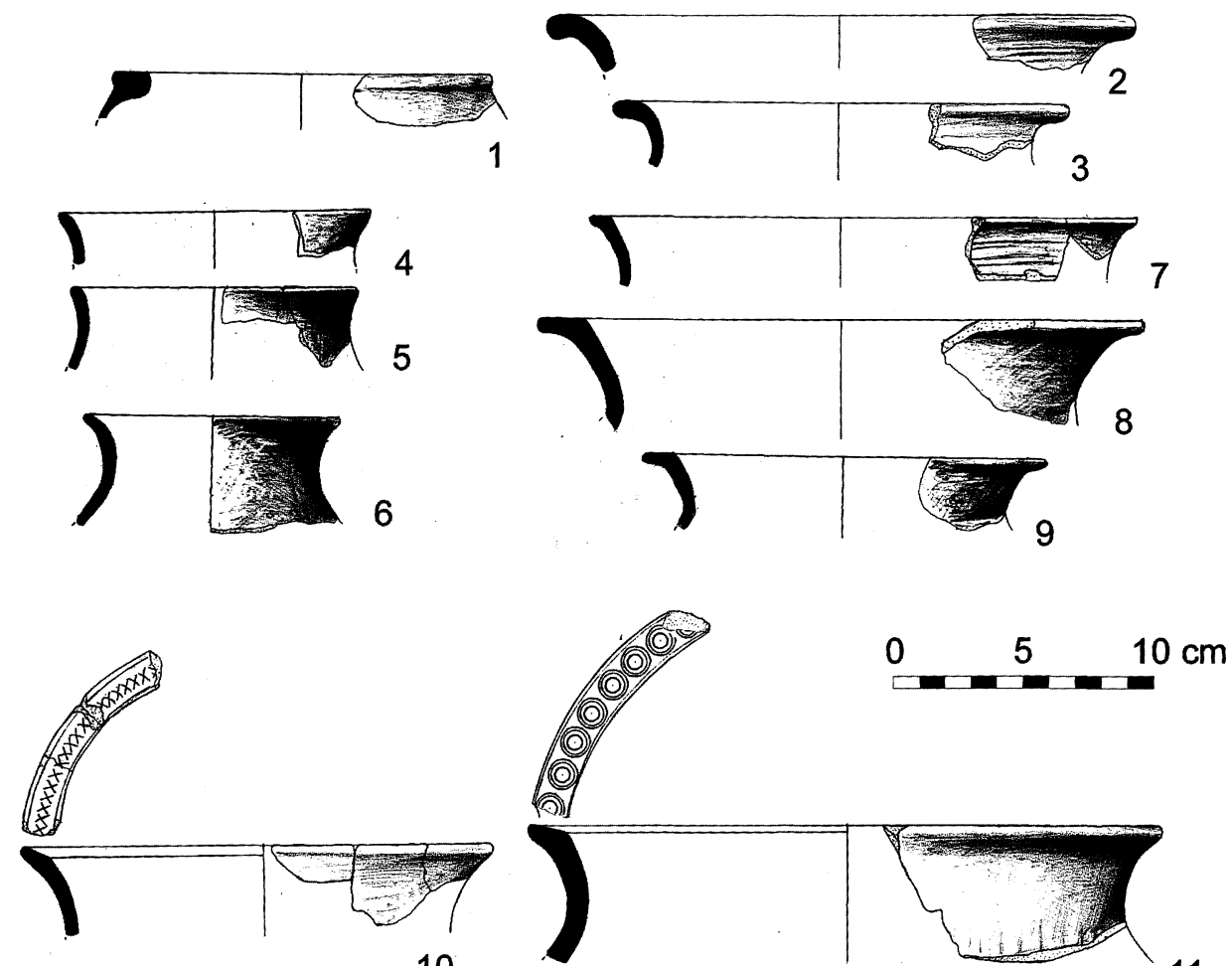

10
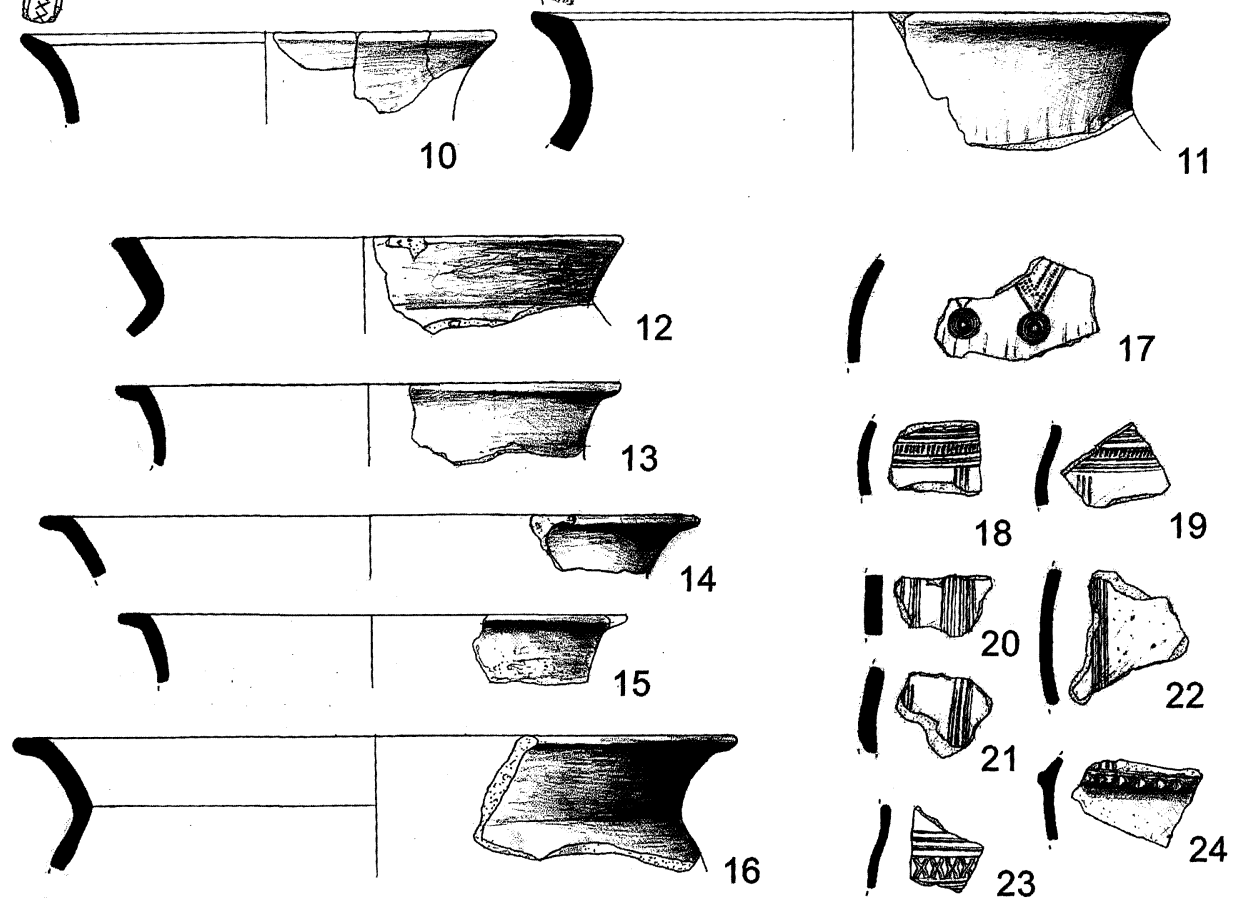

Figura 10. Materiais da Segunda Idade do Ferro do interior da cabana descobertos durante a intervención non controlada. 
perto das tradicións interiores, non polos motivos, que son claramente das Rías Baixas-Baixo Miño (estampillas de SS, medallóns), como pola porcentaxe. Só o $3,42 \%$ dos materiais exhumados na escavación clandestina amosan decoración, o que contrasta, novamente, con un sitio como A Forca, co 30-35\% dos fragmentos decorados (Carballo 1987: 117). O motivo de grandes medallóns (Figura 10, $\mathrm{n}^{\circ} 17$ ) ten os mellores paralelos en Troña (Hidalgo 1985: figs. XXIX,3, XXXII, 2) e os varios fragmentos (Figura 10, $\mathrm{n}^{\circ} 18-21$ ) corresponden a unha vasilla tipo Forca (Rey 1990-91), típica da zona sudoeste galega durante a Fase II e inicios da III. Os bordes decorados con aspas atopámolos na Fase III en Alto do Castro de Cuntis (Parcero e Cobas n.p. 02/38), cronoloxía extensible ao galbo que amosa esta decoración (Figura 10, $\mathrm{n}^{\circ} 23$ ). En xeral, bo paralelo para o noso material ofreceo o castro de Fozara (Hidalgo e Rodríguez Puentes 1988), que tamén posúe unha ubicación interior e ao mesmo tempo meridional (atópase a só 15 qm lineais de Pena Redonda). En xeral poderíase falar dunha mestura de tradicións tecnolóxicas meridionais / litorais e septentrionais / interiores. Non resulta tampouco sorprendente este feito, se pensamos que o xacemento ubícase xusto na liña onde previsiblemente se sitúaba a fronteira entre os galaicos lucenses e os bracarenses (o río Oitavén-Verdugo). En conclusión, os materiais recuperados no espolio, asinalan unha fase de fins da Idade do Ferro pero aínda prerromana, que quizáis se poida datar a finais do século II a.C. A nosa escavación forneceu datos semellantes.

A escavación da parte superior do muro da cabana (UE 6), que se corresponde coa súa destrucción e que non foi tocado pola Sra. Boullosa, deu algunhas decoracións brunidas e un estampado de SS recheo de raias que lembra aos motivos dalgunha peza de Fozara (Hidalgo e Rodríguez Puentes 1988, Figura 24). A vasilla máis semellante deste castro apareceu no nivel A, que pertence a Fase III da Cultura Castrexa e, posto que os brunidos xeralízanse durante os séculos II-I a.C., refórzase a cronoloxía que se apuntaba a partir dos materiais espoliados. Sen embargo, non hai materiais claramente da Fase III como son as asas en orella, fontes de asas interiores ou bordes reforzados típicos. Tampouco a decoración nos leva a esta fase. Pensamos por iso que é máis adecuado pensar nun momento serodio da Fase II.

Non obstante, unha vez que a cabana xa estaba abandonada, o lugar seguiu ocupado: por riba da estrutura de paredes curvas apareceu un muro (UE 24) de mala factura e considerable anchura que se construiu sobre o derrube da cabana da Fase II. Non se localizou chan nen pavemento relacionable con esta estrutura e tampouco material cerámico algún, polo que a súa data é descoñecida. Chama a atención a entidade do derrube (UE 23) e o seu tamaño, o que fai pensar nunha obra de certa prestancia. A construcción deste muro debeu arrasar os niveis da 
Segunda Idade do Ferro da cabana e parte incluso do muro desta, xa que non se atopou máis que unha lene pegada da súa presencia (UE 46) e ningún rastro de solos de ocupación atribuibles a aquéla.

Tamén producto dunha intervención serodia é a canle de grandes chantos (UE 20) que apareceu nos cadros $22 \mathrm{~F}-\mathrm{G}$ e con continuación cara o D e E. Sabemos que a Sra. Boullosa tocou xa esta estrutura e a destruiu parcialmente, segundo a súa propia testemuña. Na Carta Arqueolóxica menzoase esta estrutura como un forno, o que se explica polo seu aspecto: dous chantos verticais tapados por unha lousa horizontal. Para construir a canle escavouse unha fosa (UE 21) que perforou varios niveis de ocupación previos da Primeira e Segunda Idade do Ferro. No recheo apareceron materiais da Segunda Idade do Ferro (UE 31) entre os que sobrancea un fragmento decorado con estampilla de triángulos enfrentados. A canle fíxose pasar entre a parte septentrional da casa curva (UE 12 e UE 52) e a parte meridional de outra cabana curva (UE 36). Na parte final da canle a intervención furtiva furou por baixo desta e chegou aos niveis da Primeira Idade do Ferro. Aquí apareceu a vasilla de borde esvasado e profusa decoración incisa á que se fixo menzón (Figura 11).

No lado leste da cata, entre a fosa da canle e o muro UE 24 apareceron dous niveis de ocupación ben conservados: a UE 45 pertence a Segunda Idade do Ferro e correspóndese co momento de ocupación da casa circular. Forneceu bordes aristados típicos. A UE 48 debaixo dela é da Primeira Idade do Ferro e correspóndese cos niveis escavados máis recentes desta época no interior da cabana (UE 26 e 27). $\mathrm{Na}$ transición entre os dous niveis apareceu unha doa oculada púnica datable, por tipoloxía, no século VI-V a.C. Temos paralelos, descontextualizados, en Santa Trega (Carballo 1994: Figura 22, $\mathrm{n}^{\circ}$ 136-137). Posiblemente haxa que relaciona-la co nivel máis recente da Primeira Idade do Ferro, mais a súa aparición na zona alterada pola fosa obriga á cautela (Figura 12).

\section{Interior da cabana: a Primeira Idade do Ferro}

Se ben coidamos nun primeiro momento que a actividade non controlada deixara pouco sen tocar, vista a profundidade xa alcanzada e a cercanía da rocha nai na outra cata, os resultados pronto demostraron o contrario: debaixo da zona perturbada apareceu unha sucesión de estratos pouco ou nada alterados (Figura 13). Tras retirar unha capa revolta (UE 25) na que se mesturaba terra húmica depositada trala intervención anterior, restos de xabre e moitas raíces, apareceu o que fícaba dun pavemento de xabre amarelo-ocre (UE 26) por riba do cal construiuse a casa circular. Sobre o pavemento propiamente dito non apareceu material, ainda que algunhas das cerámicas da Primeira Idade do Ferro recollidas na intervención clandestina 


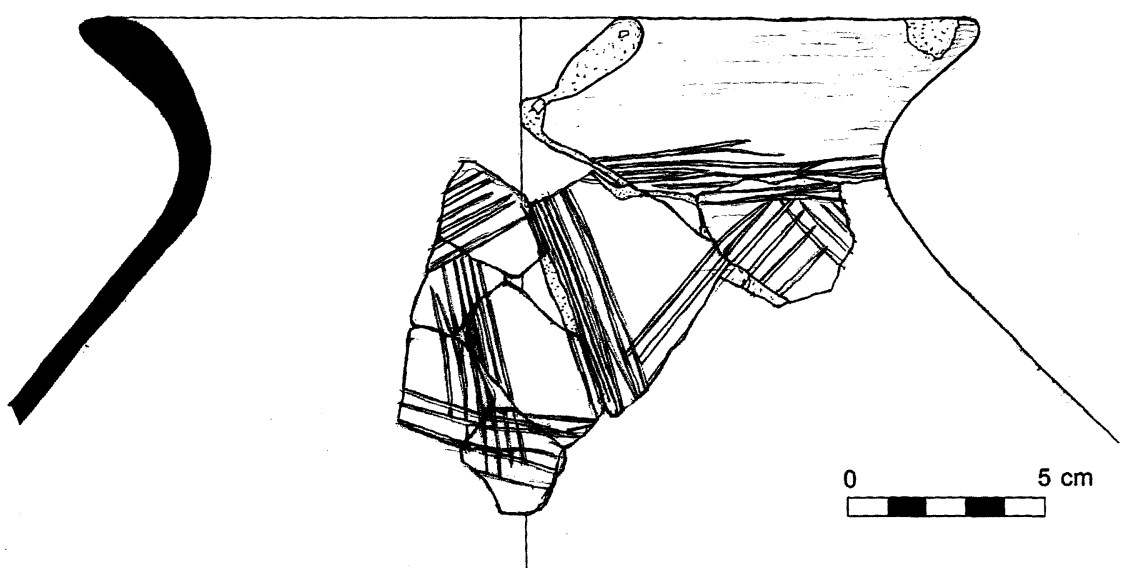

Figura 11. Vasilla da Primeira Idade do Ferro descoberta durante a intervención non controlada ، dentro da UE 33.

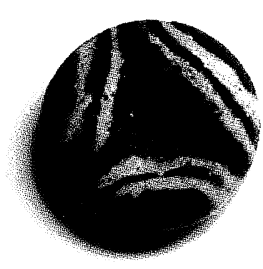

UE 41

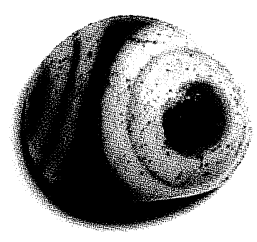

UE 45

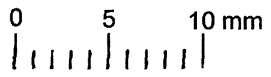

Figura 12. Doas púnicas de pasta vítrea.

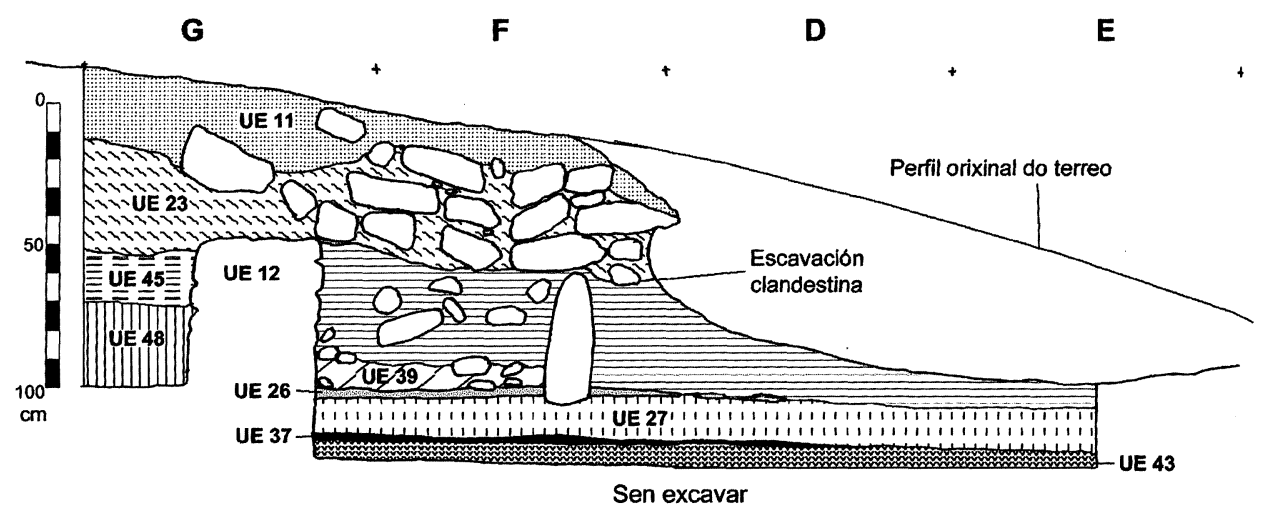

Figura 13. Estratigrafía do perfil sur do interior da Casa 2. 
(galbo con dixitacións, bordes rectos e esvasados) poden vir de aquí, habida conta que, segundo a escavadora, toda a cerámica -agás a vasilla decorada por incisiónobtívose dentro da cabana. Sobre o lado sueste do pavemento apareceu un derrube de pequenas pedras (UE 39). Isto indicaría que a estrutura á que pertencía o pavemento debía posuír muros de pedra. Alí onde o pavemento estaba roto, pola contra, localizáronse materiais da Segunda Idade do Ferro. A maior perturbación advírtese no lado oeste, e corresponde a unha fosa (UE 41) realizada quizáis no momento serodio en que se construiron a canle e mailo muro UE 24. No interior da fosa apareceu unha landra carbonizada, cerámica estampillada con SS e bordes aristados, moitos fragmentos de cerámica moi esnaquizada e unha doa púnica oculada, de datación semellante a da UE 45/48. Cómpre asinalar a grande cantidade de seixos de cuarzo que apareceron dentro do burato.

Debaixo do pavemento de xabre (UE 26) atopamos un nivel de ocupación (UE 27) con abondosos materiais (Figura 14) dos que se cartografaron formas e decoracións. A concentración maior de material dase no sector leste, que é o que sufriu menos perturbacións. Entre as cerámicas destaca un fragmento de borde ben conservado que apresenta unha arista interior. Este tipo de materiais soe caracterizar momentos tardíos dentro do primeiro Ferro: así, son frecuentes en São Julião Id, datado no século VI-V a.C. (Bettencourt 2000b: est. LXXXVI) ou nas Croas (Peña 2000: -159), con idéntica datación radiocarbónica, mentres que en Torroso (s. VIII-VII a.C.) tan só se recuperaron dous exemplares (Peña 1992: Figura 40) e ámbolos dous na última fase de vida do povoado. A este nivel de ocupación corresponde o pavemento que identificamos coa UE 37. Sobre este, no centro da cabana, apareceron dúas trabes carbonizadas (UE 35), entre as que se recuperaron fragmentos de landras (Figura 15). O carbón das trabes recolleuse para a súa datación. O pavemento UE 37 atópase bastante desfeito -ao igual que o máis recente UE 26- o que explica a ausencia de material in situ. Debaixo da UE 37 apareceu un estrato de terra orgánica negra (UE 43) sen apenas materiais, no cal se construiron dúas estruturas de planta curva: a máis antiga era de material perescible e só se conservou a fosa perimetral (UE 44) que a definía e máis dous buratos de poste. Máis recente, pero todavía por baixo da UE 37 apareceu un muro de pedra (UE 38) pertencente a unha casa probablemente circular, co seu derrube (UE 40) (Figura 16). A casa circular continúa por fora da cabana da Segunda Idade do Ferro (UE 12). Por limitacións de tempo non foi posible escavar o estrato orgánico (UE 43) na súa totalidade. É posible que aínda haxa máis niveis da Primeira Idade do Ferro e mesmo do Bronce Final por debaixo da UE 43. O material que aparece por baixo do pavemento UE 37 redúcese a catro fragmentos amorfos. 


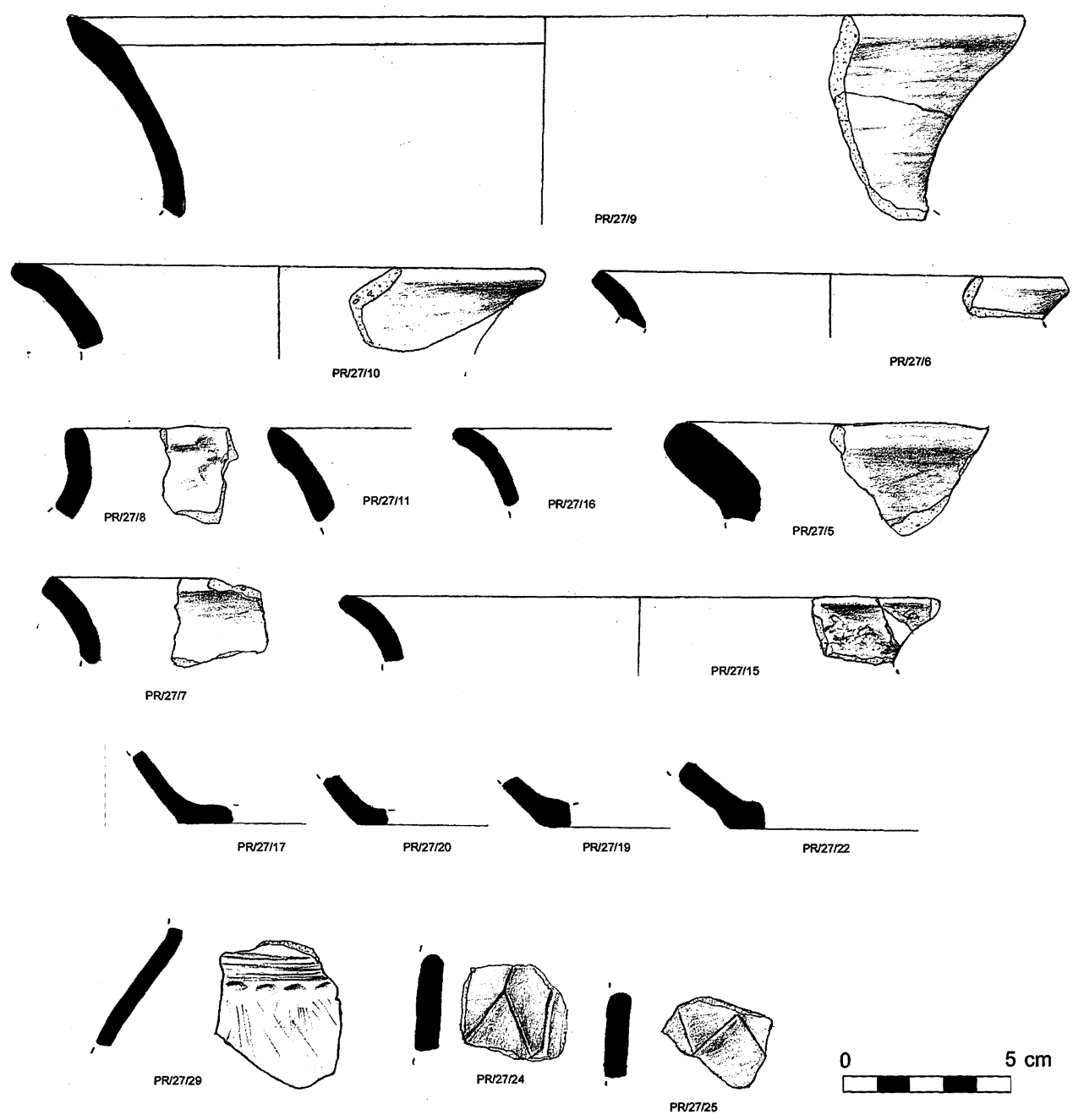

Figura 14. Materiais da UE 27 (Primeira Idade do Ferro). 


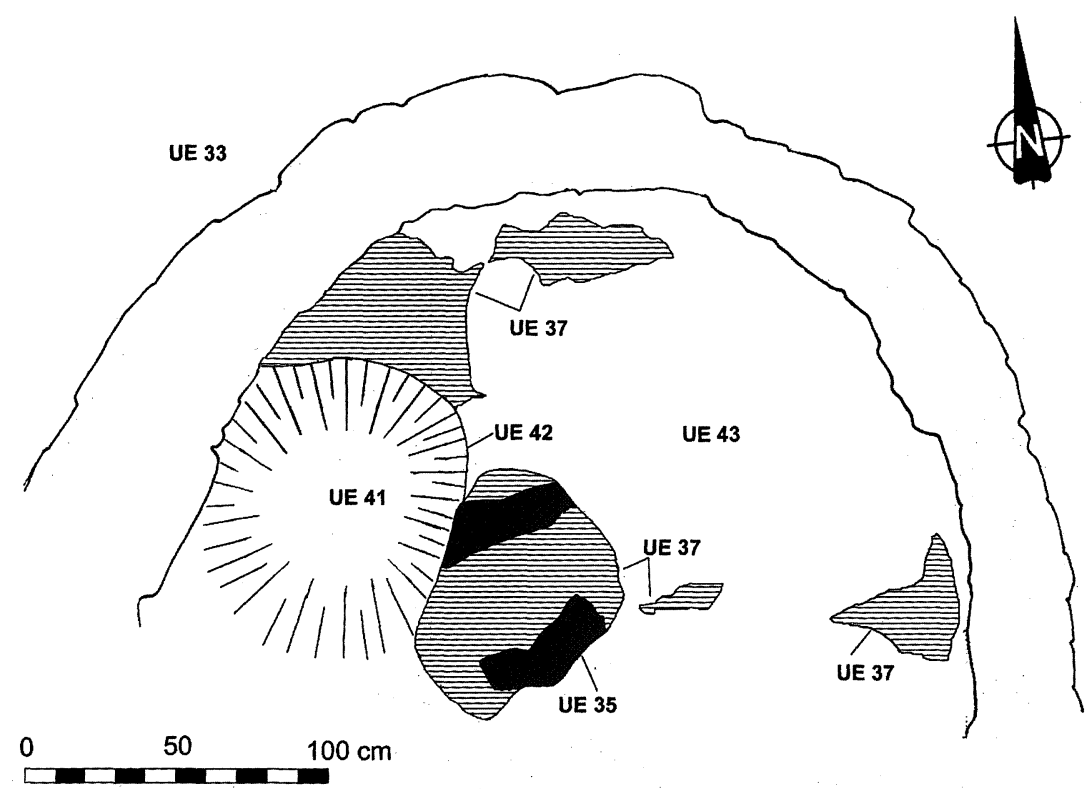

Figura 15. Pavemento (UE 37) e trabes (UE 35) da penúltima ocupación da Primeira Idade do Ferro.

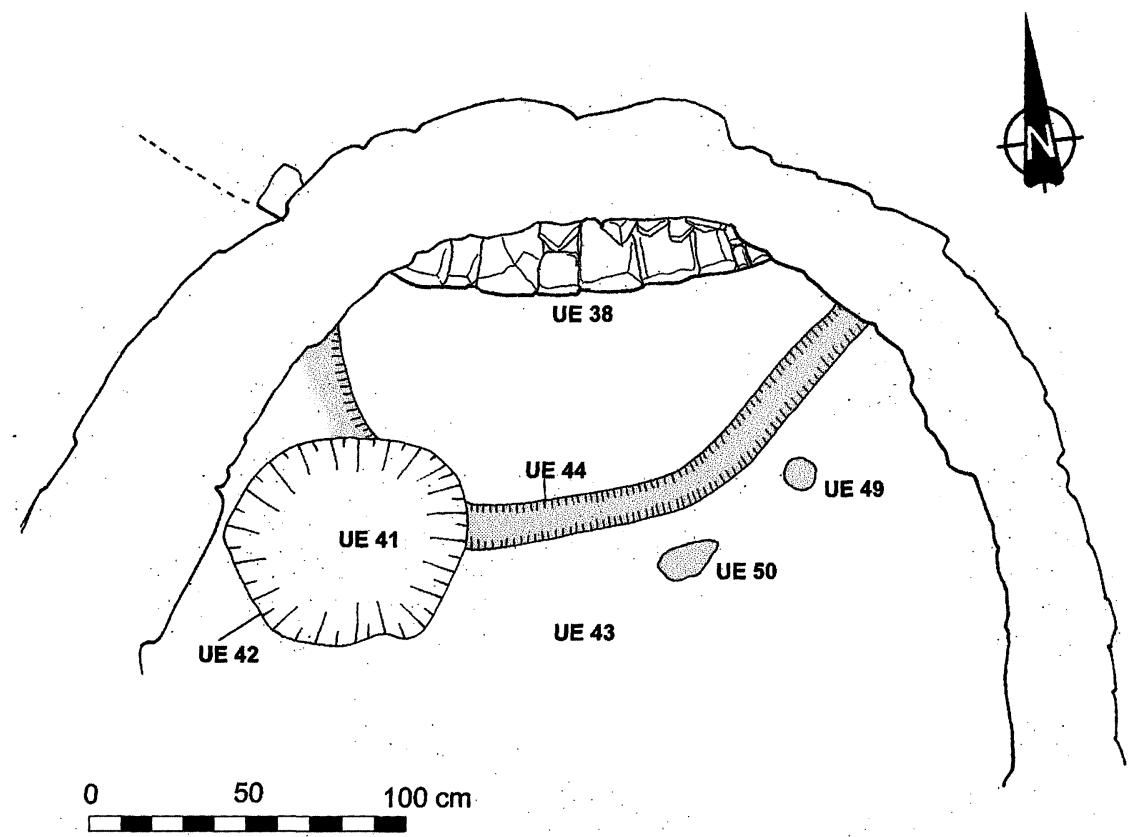

Figura 16. Estrutura de pedra e fosa de xabre con buratos de poste dos momentos máis antigos da Primeira Idade do Ferro. 


\section{SÍNTESE E CONCLUSIÓNS}

- A casa 1 construiuse nun momento indeterminado da Segunda Idade do Ferro, moi probablemente dentro da Fase II (s. IV-II a.C.). O lugar xa fora ocupado previamente durante a Primeira Idade do Ferro, momento no que non existían estruturas de pedra e as perescibles reducíanse a unha cubeta de xabre de función descoñecida. Non se pode descartar que a ocupación máis antiga fose perturbada pola da Fase II, pois a cabana asenta os alicerces sobre a rocha nai.

- A casa 2 é probablemente coetánea da casa 1. A ocupación previa aquí e máis complexa e tivo polo menos tres fases. Da máis antiga a máis recente: 1) estrutura perescible curva (UE 44).

2) estrutura circular ( $¿$ ?) de pedra (UE 38).

3) estrutura indeterminada que se dotou dun pavemento de xabre (UE 37).

4) estrutura probablemente de pedra (derrube UE 39) cun pavemento de xabre (UE 26).

- Por riba da casa 2 construiuse unha estrutura de pedra aparentemente lineal da que se descoñece a data e perforando os niveis anteriores fíxose unha canle ao norte da casa 2, con data probable de finais do Ferro.

- Xunto a casa 1 e a casa 2 apareceron sendas construccións coetáneas de pranta curva das que apenas se documentou máis que a súa presencia.

O xacemento de Pena Redonda é, polo tanto, un asentamento de longa e complexa ocupación, que testemuña o uso da arquitectura pétrea desde momentos antigos da Primeira Idade do Ferro. Isto resulta até certo punto abraiante en tanto que estamos nun xacemento da montaña, mentres que os sitios que polo de agora forneceron arquitecturas permanentes antigas están en ambientes litorais ou prelitorais: Coto da Pena, Torroso, As Croas, Neixón Pequeno (Silva 1986: 34-35, Peña 1992 e 2000, Acuña 1976). A única excepción sería quizáis a gran cabana de Alto do Castro de Cuntis (Parcero e Cobas n.p.), que se atopa a unha distancia semellante da costa. Durante a Segunda Idade do Ferro a organización do espacio amosa unha acumulación de estruturas densa, segundo pon de manifesto o facto de que no espacio limitado das nosas sondaxes aparecesen trazas de catro estruturas, con muros que case se xuntan. Este tipo de organización do espacio lembra ao da zona sudoeste galega durante as mesmas datas. Polo que respecta as importacións púnicas, a súa presencia enmárcase dentro da corrente comercial que chega as costas do Noroeste durante o século V a.C. Neste caso, o facto de que se trate dun lugar de interior achégao a outros casos coñecidos, como Castrovite ou Castromao, con 


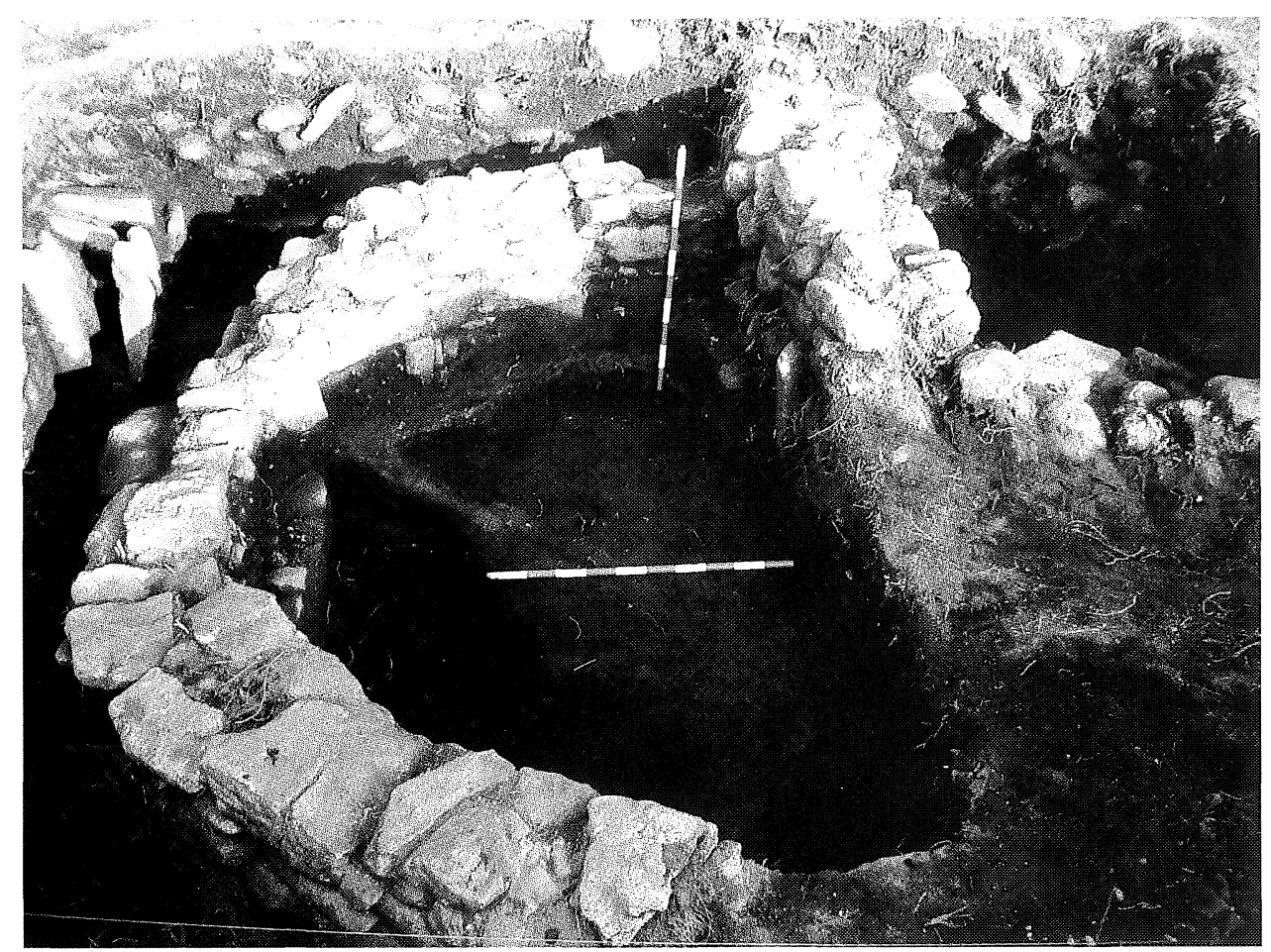

Figura 17. Estado final da cata unha vez rematada a escavación.

importacións en datas semellantes. A fin do asentamento veu durante os inicios da Fase III e seguramente debeuse a un fenómeno de sinecismo en beneficio do veciño castro de Gaxate, situado -como dixemos-a un quilómetro lineal. Este castro amosa un gran desenvolvemento durante o final da Idade do Ferro, segundo revela a gran ampliación que se detecta nese momento no povoado. Nela teñen aparecido estruturas circulares e rectangulares e elementos decorativos en pedra: fragmentos de frisos, ombreiras e padieras e dúas cabezas cortadas (Calo 1994: 271-274).

A escavación arqueolóxica amosou, en conclusión, a existencia dun asentamento de longa vida e dunha considerable complexidade, o que chama a atención dado o lugar afastado e a paisaxe discordante para o momento cultural no cal se encadra. Coidamos que sería necesario rematar as sondaxes previstas na posible muralla e máis na estrutura que agora sabemos cuadrangular para poder definir mellor o carácter atípico e a funcionalidade deste xacemento. 


\section{AGRADECEMENTOS}

A escavación non tería sido posible se non fose pola axuda profesional, desinteresada e xenerosa de Xosé Lois Ladra Fernandes, Rafael Rodríguez Martínez, Carlos Marín Suárez, Diego Piay Augusto, José Ángel Acuña Farto, Álvaro Falquina Aparicio e Jorge García García. As planimetrías son de José Ángel Acuña Farto. A todos eles as miñas máis sinceiras gracias. Gracias a Xurxo Ayán tamén, que nos botou unha man cando facía boa falta.

A Sra. Dna. Maria Albertina Boullosa acompañoume ao xacemento, amosoume as cabanas que foron espoliadas e deume informacións valiosas sobre o sitio e mailas súas descobertas. Ao Sr. D. Vicente Iglesias, Presidente da Comunidade de Montes de Forzáns agradézolle a dilixencia coa que permitiu as sondaxes e o interese amosado polos nosos traballos. Antonio de la Peña púxome ao corrente da historia dos achádegos e do sitio e deume as pistas sobre o seu carácter atípico. Á profesora Dra. Marisa Ruiz-Gálvez do Departamento de Prehistoria da UCM agradézolle o préstamo do equipo topográfico e de material de escavación e ao Dr. Mariano Torres as matizacións na cronoloxía das doas púnicas.

\section{BIBLIOGRAFÍA}

ACUÑA CASTROVIEJO, F. 1976. Excavaciones en el castro de «O Neixón». Noticiario Arqueológico Hispánico. Prehistoria 5: 327-330.

BALSEIRO, A. 1994. El oro prerromano en la provincia de Lugo. Museo Provincial de Lugo / Servicio de Publicaciones, Diputación de Lugo.

BETTENCOURT, A.M. 2000a. O vale do Cávado dos finais do III milénio aos meados do I milénio AC: sequéncias cronológico-culturais. Actas do III Congresso Peninsular de Arqueologia IV, Vila Real: 79-93.

BETTENCOURT, A.M. 2000b. O Povoado de S. Julião, Vila Verde, Norte de Portugal, nos finais da Idade do Bronze e na transição para a Idade do Ferro. Cadernos de Arqueología, Monografías 10, Braga.

CALO LOURIDO, F. 1994. A plástica castrexa galaico-portuguesa. 2 vols. Fundación Barrié de la Maza, A Coruña.

CARBAllo ARCEO, X. 1987. Castro da Forca. Campaña de 1984. Arqueoloxía / Memorias. Xunta de Galicia, A Coruña.

CARBALLO ARCEO, X. 1990. Los castros de la cuenca media del río Ulla y sus relaciones con el medio físico. Trabajos de Prehistoria 47: 161-199.

CARBALlO ARCEO, X. 1994. Catálogo dos materiais arqueolóxicos do museu do Castro de Santa Trega: Idade do Ferro. Padroado do Monte de Santa Trega, A Guarda.

Cuadernos de Estudios Gallegos, Tomo LII, Fascículo 118, Santiago 2005. (Págs. 173 - 197) 
CARBALLO ARCEO, X. 1996. O espacio na cultura castrexa galega. En A Cultura Castrexa galega a debate (J. M. Hidalgo, ed.). Instituto de Estudios Tudenses, Tui: 107-138.

CRIADO BOADO, F. 1993. Límites y posibilidades de la arqueología del paisaje. SPAL 2: 9-55.

HIDALGO CUÑARRO, J. M. y RODRÍGUEZ PUENTES, E. 1988. Castro de Fozara. Campaña de 1984. Arqueoloxía/Memorias, 9. Xunta de Galicia, Santiago de Compostela.

LÓPEZ CUEVILLAS, F. 1951. Las joyas castreñas. Instituto de Arqueología y Prehistoria «Rodrigo Caro», CSIC, Madrid.

MARTINS, M. 1989. O castro do Barbudo, Vila Verde. Resultados das campanhas realizadas entre 1983 e 1985. Cadernos de Arqueologia 3, Monografias, Braga.

MEIJIDE CAMESELLE, G. 1988. Las espadas del Bronce Final en la Peninsula Ibérica. Publicacións da Universidade de Santiago de Compostela, Santiago de Compostela.

PARCERO OUBIÑA, C. 2001. La construcción del paisaje social en la Edad del Hierro del Noroeste Ibérico. Tesis inédita. Departamento de Historia I. Facultade de Xeografía e Historia. Universidade de Santiago de Compostela.

PARCERO OUBIÑA, C. e COBAS FERNÁNDEZ, I. (n.p.): Alto do Castro (Cuntis, Pontevedra). Sintesis de resultados y estudio de materiales. Campaña de 1993.

PEÑA SANTOS, A. de la. 1992. Castro de Torroso (Mos, Pontevedra). Síntesis de las memorias de las campañas de excavaciones 1984-1990. Arqueoloxía/Memorias11, Xunta de Galicia, Santiago de Compostela.

PEÑA SANTOS, A. de la 2000. Castro de As Croas (Salcedo, Pontevedra). Brigantium 12: $153-$ 160.

Rey Castiñeiras, J. 1990-91. Cerámica indígena de los castros costeros de la Galicia occidental: Rías Bajas. Valoración dentro del contexto general de la Cultura Castreña. Castrelos 3-4: 141163.

SILVA, A.C.F. da 1986. A Cultura Castreja do Noroeste de Portugal. Câmara. Municipal de Paços de Ferreira, Paços de Ferreira. 